\title{
ALOKASI ANGGARAN PUBLIK DAN PENGENTASAN KEMISKINAN DI PULAU KALIMANTAN
}

\author{
Muliati \\ Universitas Mulawarman \\ Dyah Wulansari \\ Rossanto Dwi Handoyo \\ Universitas Airlangga \\ Alamat Korespondensi: muliati@feb.unmul.ac.id
}

\begin{abstract}
Inequality of income distribution and poverty rate are two of development indicators implied from budget allocation on public spending. These two indicators can also be considered as a success in development in term of low inequality and small number of the poor. Based on the concept this article aims to confirm whether budget allocation in Kalimantan's local government level affects the distribution of income and poverty. The analysis was conducted using smartPLS software version 2 by utilizing Regional Government Budget (APBD) panel data of 5 provinces and 61 districts/cities and provincial government within 3 years period. The results showed that government spending in the fields of health, education, economy, and social protection has a significant effect on the distribution of income in the study area, even though the evidence of its direct effect on poverty alleviation cannot be proven statistically. Moreover, income distribution in this study is known to have a significant effect on poverty which is a reflection variable of 3 indicators, namely the percentage of poor population, the depth and severity of poverty.
\end{abstract}

\section{KATA KUNCI:}

Pengeluaran Pemerintah, Ketimpangan Pendapatan, Kemiskinan, Kalimantan

\begin{abstract}
ABSTRAK
Indikator keberhasilan pemerintah dalam pembangunan dapat dilihat melalui beberapa hal seperti rendahnya ketimpangan distribusi pendapatan dan angka kemiskinan. Kedua hal tersebut dapat dicapai melalui peran pemerintah dalam ranah kebijakan anggaran terkait alokasi pengeluaran pemerintah untuk kepentingan publik. Berangkat dari konsep dimaksud artikel ini bertujuan untuk mengkonfirmasi apakah kebijakan anggaran di level pemerintah daerah di Pulau Kalimantan berpengaruh terhadap distribusi pendapatan dan kemiskinan. Analisis dilakukan dengan menggunakan software smartPLS versi 2 dengan memanfaatkan data panel APBD 5 provinsi dan 61 kabupaten/kota dan pemerintah provinsi dalam kurun waktu 3 tahun. Hasil analisis secara parsial menunjukkan bahwa pengeluaran pemerintah dalam bidang kesehatan, pendidikan, ekonomi, dan perlindungan sosial berpengaruh signifikan terhadap distribusi pendapatan di wilayah penelitian. Variabel kemiskinan dipengaruhi secara negatif dan signifikan oleh ketimpangan distribusi pendapatan, sedangkan variabel pengeluaran pemerintah berpengaruh negatif terhadap kemiskinan meskipun perannya terhadap pengentasan kemiskinan tidak dapat dibuktikan secara nyata.
\end{abstract}

KLASIFIKASI JEL:

H53, I31

\section{CARA MENGUTIP:}

Muliati, Wulansari, D., \& Handoyo, R.D. (2019). Alokasi anggaran publik dan pengentasan kemiskinan di pulau kalimantan. Indonesian Treasury Review: Jurnal Perbendaharaan, Keuangan Negara dan Kebijakan Publik, 4(4),371-384. 


\section{PENDAHULUAN}

\subsection{Latar Belakang}

Telaah teoritis dan empiris menyebutkan bahwa pengeluaran pemerintah di bidang sosial seperti pendidikan, kesehatan, ekonomi, infrastruktur dan perlindungan kesehatan paling tidak berpengaruh terhadap dua hal yaitu pertumbuhan ekonomi dan ketimpangan distribusi pendapatan. Disebutkan pula bahwa pengeluaran pemerintah secara umum berperan sebagai mekanisme untuk mendorong pertumbuhan ekonomi dan memperbaiki inefisiensi/kegagalan pasar (Romer et al., 1989). Di negara-negara maju pengeluaran pemerintah terutama di bidang sosial memiliki porsi besar, dan hal ini merupakan indikator besarnya komitmen pemerintah dalam mengurangi ketimpangan pendapatan dan kemiskinan.

Pengeluaran pemerintah sebagai salah satu strategi kebijakan fiskal yang dilakukan dimaksudkan untuk memenuhi fungsi alokasi sebagai implementasi dari tujuan pembangunan yang pro poor. Fungsi alokasi ini dimaksudkan untuk mengatur bagaimana pendapatan negara dapat dinikmati oleh rakyat melalui fasilitas kesehatan, pendidikan, aktivitas ekonomi, dan lain sebagainya. Hasil dari pembangunan yang pro poor dapat dilihat dari ketimpangan distribusi pendapatan dan angka kemiskinan. Di Indonesia ketimpangan distribusi pendapatan diukur melalui rasio Gini yang bervariasi antar daerah satu dengan lainnya. Data Badan Pusat Statistik menunjukkan bahwa di pertengahan tahun 2019 terjadi ketimpangan distribusi yang cukup besar di level provinsi, dengan tingkat ketimpangan tertinggi di DI Yogyakarta, disusul kemudian Gorontalo, Jawa Barat, Sulawesi Tenggara, DKI Jakarta, dan Papua. Keenam provinsi tersebut memiliki karakteristik yang berbeda-beda baik dari sisi ekonomi maupun geografis, tetapi secara umum seluruhannya berada di luar Pulau Kalimantan.

Pada level provinsi ketimpangan distribusi pendapatan dan kemiskinan Kalimantan menjadi permasalahan tersendiri karena meskipun hampir semua provinsi memiliki kekayaan alam yang besar tapi Gini rasio masih belum mengalami penurunan signifikan. Demikian pula halnya dengan pengeluaran pemerintah yang sepanjang periode penelitian menunjukkan progres yang cukup baik tetapi tidak dibarengi dengan perubahan angka kemiskinan yang tidak signifikan. Kondisi ini mendorong penulis untuk mengetahui lebih mendalam tentang bagaimana pengaruh pengeluaran pemerintah di wilayah Kalimantan terutama di bidang sosial yaitu pengeluaran bidang kesehatan, pendidikan, ekonomi dan perlindungan sosial terhadap ketimpangan distribusi pendapatan dan kemiskinan.

\subsection{Rumusan Masalah}

Berdasarkan latar belakang yang sudah dipaparkan sebelumnya maka rumusan masalah yang disusun dalam penelitian ini adalah sebagai berikut:

1) Bagaimana pengaruh pengeluaran pemerintah terhadap ketimpangan pendapatan di Pulau Kalimantan?

2) Bagaimana pengaruh pengeluaran pemerintah dan ketimpangan distribusi pendapatan terhadap kemiskinan di Pulau Kalimantan?

\subsection{Tujuan Penelitian}

Tujuan penelitian ini dimaksudkan untuk menjawab gap research yang dijabarkan dalam latar belakang dan disusun dalam rumusan masalah. Adapun tujuan penelitian ini adalah sebagai berikut:

1. Mengetahui bagaimana pengaruh pengeluaran pemerintah terhadap ketimpangan pendapatan di Pulau Kalimantan

2. Mengetahui bagaimana pengaruh pengeluaran pemerintah dan ketimpangan distribusi pendapatan terhadap kemiskinan di Pulau Kalimantan

\subsection{Hipotesis}

Berdasarkan rumusan masalah yang telah diketahui sebelumnya dan hasil telaah teoritis dan empiris maka hipotesis yang dikembangkan dalam penelitian ini adalah sebagai berikut:

1. Terdapat hubungan positif dan signifikan antara pengeluaran pemerintah bidang pendidikan, kesehatan, ekonomi dan perlindungan sosial terhadap ketimpangan distribusi pendapatan di Kalimantan

2. Terdapat hubungan positif dan signifikan antara pengeluaran pemerintah dan ketimpangan distribusi pendapatan terhadap kemiskinan di Pulau Kalimantan

\section{LANDASAN TEORI}

Kemiskinan adalah masalah pokok dalam pembangunan yang sampai dengan saat ini masih menjadi masalah utama sebagian besar negaranegara di dunia. Banyak peneliti dan lembaga yang memformulasi ukuran yang digunakan untuk mengidentifikasi kemiskinan seperti Bank Dunia (World Bank) dengan konsep Garis Kemiskinan dan klasifikasi berdasarkan pemikiran Foster, Greer, dan Thorbecke, Department for International Development (DFID) yang menggunakan Kerangka Kehidupan Berkelanjutan untuk mengukur kerentanan untuk jatuh miskin, dan lain sebagainya. Terlepas dari metode yang digunakan kemiskinan di Indonesia diukur oleh Badan Pusat Statistik (BPS) yang merujuk pada formulasi Bank Dunia dengan klasifikasi persentase penduduk miskin (P0), indeks kedalaman kemiskinan (P1), dan indeks keparahan kemiskinan (P3). Berbeda dengan BPS yang menggunakan ukuran pengeluaran, Badan Perencanaan Nasional mendefinisikan kemiskinan dengan mengakomodir beberapa sudut pandang 
memalui kemampuan seseorang untuk memenuhi hak atas kebutuhan dasar seperti pangan, sandang, papan, kesehatan, pendidikan, pekerjaan, rasa aman, dan hak partisipasi dalam kehidupan sosial dan politik.

Ketimpangan distribusi pendapatan di berbagai negara diukur dengan beberapa indikator seperti Rasio Gini dan indikator pendapatan kriteria Bank Dunia. Rasio Gini secara teknis adalah perbandingan antara luas bidang dalam kurva Lorenz dengan garis diagonal yang membujur dari kiri bawah ke kanan atas. Garis ini disebut juga dengan garis pemerataan sempurna yang menunjukkan penerimaan pendapatan yang sama dengan penduduk. Jika garis kurva Lorenz semakin jauh dari garis pemerataan dapat dikatakan bahwa ketimpangan pendapatan antar penduduk semakin tinggi. Sedangkan jika garis kurva Lorenz semakin mendekati garis pemerataan maka ketimpangan pendapatan penduduk di wilayah tersebut semakin rendah. Bank Dunia mengukur ketimpangan pendapatan dengan menggunakan metode rasio dispersi persentil. Pada metode ini pendapatan diukur melalui pengeluaran konsumsi yang dibagi berdasarkan share 0-5 persentil dan akan diketahui ketimpangan pendapatan pada, katakanlah, 20\% penduduk terbawah atau $20 \%$ penduduk teratas tergantung pada persentil yang digunakan. Selain kedua indikator tersebut, dikenal pula dua indikator lain yang populer yaitu Generalized Entropy Measure dan Atkinson's Inequality Measure. Namun demikian yang banyak digunakan adalah dua indikator yang disebutkan sebelumnya.

Studi mengenai pengaruh pengeluaran pemerintah terhadap kemiskinan maupun pengeluaran pemerintah terhadap distribusi pendapatan telah banyak diteliti dengan hasil yang berbeda-beda. Penelitian yang dilakukan di negaranegara OECD dengan menggunakan data panel dari tahun 1980-1980 dan beberapa variabel kontrol seperti tingkat pengangguran, jumlah pemilih dalam pemilihan umum, persentase penduduk lanjut usia dan lag pengeluaran pemerintah, diketahui bahwa ketimpangan distribusi pendapatan di 18 negara Organization for Economic Cooperation and Development (OECD) tersebut disebabkan oleh rendahnya pengeluaran di bidang sosial (Moene \& Wallerstein, 2001). Namun demikian patut dicatat bahwa penelitian tersebut tidak mengklasifikasi perbedaan karakteristik masing-masing negara dan menggunakan data pengeluaran pemerintah secara keseluruhan tanpa mempertimbangkan alokasi pengeluaran pada bidang tertentu sehingga bisa saja hasilnya akan berbeda jika mengakomodir setidaknya kedua hal tersebut. Beberapa penelitian (Artige \& Cavenaile, 2004; Bénabou, 2000; Bleaney, Gemmell, \& Kneller,
2001) di Amerika Serikat, negara-negara Eropa Barat dan OECD menyebutkan bahwa pengeluaran pemerintah yang pro-growth dan pro-income inequality memiliki karakteristik pengeluaran pemerintah yang relatif besar di bidang kesehatan, pendidikan, dan pengeluaran untuk infrastruktur. Sedangkan pengeluaran pemerintah untuk bidang lain cenderung kurang berpengaruh terhadap penurunan ketimpangan distribusi pendapatan.

Beragam penelitian dilakukan untuk melihat hubungan parsial pengeluaran pemerintah bidang pendidikan terhadap ketimpangan distribusi pendapatan. Pun sama halnya dengan pengeluaran pemerintah secara keseluruhan, alokasi parsial juga mengindikasikan temuan yang berbeda-beda. Secara teoritis pendidikan diharapkan dapat menurunkan kesenjangan pendapatan antar penduduk, di mana dengan mendapatkan pendidikan yang layak kesempatan kerja yang dapat diperoleh semakin besar dan pada akhirnya akan menurunkan kesenjangan pendapatan. Hubungan negatif antara pengeluaran pemerintah bidang pendidikan terhadap ketimpangan pendapatan ini ditelaah lebih dalam pada sejumlah artikel (Barro, 2000; Coady \& Dizioli, 2017; Glomm \& Ravikumar, 1992; Jianu, 2018; Ospina, 2014; Ulu, 2018). Sedangkan temuan hubungan negatif antar kedua variabel dapat dibuktikan secara empiris oleh beberapa penulis (Checchi, 2000; Keller, 2010; Sylwester, 2002). Selain hubungan positif dan negatif antara pengeluaran pemerintah bidang pendidikan dan ketimpangan pendapatan terdapat hubungan U terbalik antara kedua variabel tersebut dengan melalui variabel pertumbuhan ekonomi di negara-negara OECD (Artige \& Cavenaile, 2004)

\section{METODOLOGI PENELITIAN}

\subsection{Sumber Data}

Penelitian ini menggunakan data sekunder yang diperoleh dari publikasi Anggaran Pembangunan dan Belanja Daerah se-Kalimantan secara daring oleh Kementerian Keuangan Direktorat Jenderal Perimbangan Keuangan. ${ }^{1}$ Sedangkan data tentang ketimpangan pendapatan dan kemiskinan diperoleh dari publikasi daring Badan Pusat Statistik di masing-masing provinsi dan kabupaten kota masing-masing wilayah penelitian. Terdapat 61 kabupaten/kota dan pemerintah provinsi yang dianalisis dalam kurun waktu 3 (tiga) tahun yaitu tahun 2015 sampai dengan 2017, meliputi seluruh kabupaten dan kota serta pemerintah provinsi Kalimantan Barat, Kalimantan Selatan, Kalimantan Tengah, Kalimantan Timur, dan provinsi termuda di Indonesia, Kalimantan Utara. Pembatasan kurun waktu penelitian ini dimaksudkan untuk memperkecil ketidakseimbangan struktur data

\footnotetext{
${ }^{1}$ http://www.djpk.kemenkeu.go.id/?p=5412 diakses tanggal 6 November 2019
} 
mengingat tidak semua daerah memiliki data yang lengkap. Ketidaklengkapan informasi yang terjadi selama proses pengumpulan data diatasi dengan teknik interpolasi atau metode lain yang secara ilmiah dapat dipertanggungjawabkan.

Ketersediaan data yang relatif tidak seimbang antar kabupaten/kota/provinsi tidak memungkinkan penggunaan data runtut waktu dalam penelitian sehingga data panel menjadi pilihan terbaik dalam menganalisis data yang tersedia. Dibandingkan dengan data kerat lintang, informasi dalam titik observasi yang sama pada data panel lebih variatif sehingga penggunaan data panel dapat meningkatkan presisi pada model yang diestimasi dari data tersebut. Namun demikian di luar kelebihan ini patut diperhatikan kemungkinan terjadinya korelasi dan saling ketergantungan pada galat antar waktu dari model (Hoechle, 2007).

\subsection{Variabel Penelitian}

Penelitian ini menggunakan dua variabel laten eksogen yaitu pengeluaran pemerintah dan ketimpangan pendapatan dengan satu variabel endogen kemiskinan. Variabel pengeluaran pemerintah terdiri atas pengeluaran pemerintah bidang pendidikan, kesehatan, ekonomi, dan bantuan sosial, sedangkan variabel ketimpangan pendapatan merupakan refleksi dari angka koefisien Gini. Kemiskinan diukur dengan menggunakan variabel persentase penduduk miskin, indeks kedalaman kemiskinan, dan indeks keparahan kemiskinan. Matriks variabel yang digunakan dalam penelitian dapat dilihat pada tabel 1 di lampiran.

\subsection{Langkah Analisis}

Permasalahan yang dibahas dalam penelitian ini dianalisis dengan menggunakan teknis Partial Least Square (PLS) atau sering disebut sebagai soft modeling. Analisis PLS menjadi pilihan karena analisis ini memungkinkan penggunaan ukuran sampel yang relatif tidak besar, dapat mengakomodir sifat indikator baik reflektif maupun formatif, dan tidak membutuhkan pemenuhan asumsi multivariat. Lebih lanjut PLS dapat digunakan untuk mengkonfirmasi teori selain digunakan untuk membangun hubungan variabel penelitian dengan tujuan untuk pengujian preposisi. Adapun langkah-langkah yang perlu dilakukan dalam analisis sebelum sampai pada kesimpulan penelitian adalah sebagai berikut:

1. Menentukan model berbasis konsep dan teori untuk merancang model struktural Model struktural ditentukan berdasarkan pada rumusan masalah dan uji hipotesis yang dibangun dalam penelitian. model ini merupakan hubungan antar variabel laten dalam penelitian yang berbasis pada teori dan bukti-bukti empiris dari penelitian yang sudah dilakukan sebelumnya (inner model)

2. Merancang model pengukuran
Model pengukuran (outer model) dimaksudkan untuk menentukan apakah indikator yang digunakan sebagai konstruk variabel laten bersifat reflektif atau formatif. Sifat indikator pembentuk variabel ini akan menentukan dasar alat analisis yang akan digunakan.

3. Konstruksi diagram jalur

Hasil penentuan inner dan outer model pada langkah 1 dan 2 akan dituangkan dalam bentuk diagram jalur untuk menggambarkan konstruk variabel laten dan hubungan antara variabel eksogen dan endogen.

4. Konversi diagram jalur ke dalam sistem persamaan

Sistem persamaan dapat dibentuk dari outer dan inner model, dimana:

a) Outer model, disebut juga sebagai measurement model adalah hubungan antara variabel laten dengan indikator pembentuknya. Persamaan ini digunakan untuk mendefinisikan karakteristik variabel tertentu dengan variabel pembentuknya (variabel manifest)

b) Inner model adalah hubungan antar variabel laten (model struktural) berdasarkan konsep teoritis.

5. Estimasi/pendugaan parameter

Langkah selanjutnya adalah melakukan pendugaan parameter dengan menggunakan metode kuadrat terkecil (ordinary least square) dengan cara iterasi dan koefisien jalur. Proses perhitungan dilakukan dengan secara iteratif dan akan berhenti saat sudah menemukan titik konvergen. Pendugaan parameter dengan menggunakan metode PLS meliputi tiga hal, yaitu:

a) Menentukan estimasi bobot untuk mendapatkan skor variabel laten dengan teknik weights estimate

b) Menghubungkan variabel laten dan loading factor pada masing-masing variabel manifes

c) Menentukan konstanta dan intersep untuk setiap variabel manifes dan laten

6. Menentukan kelayakan model (Goodness of Fit)

a) Outer model

Outer model dikatakan layak dapat dilihat dari 3 uji yaitu convergent validity, discriminant validity, dan composite reliability. Convergent validity terpenuhi jika terdapat korelasi antara skor indikator dan variabel laten dengan nilai loading antara 0.5 sampai dengan 0.6. Discriminant validity diketahui dengan cara membandingkan nilai akar kuadrat dari Average Variance Extracted (AVE) 
setiap konstruk dengan korelasi antar konstruk lain pada model dimaksud. Jika akar kuadrat AVE memiliki nilai konstruk yang lebih besar dari korelasi seluruh konstruk maka nilai discriminant validity dikategorikan baik. Adapun nilai standar yang direkomendasikan adalah $>0.5$. Tujuan uji Composite Reliability adalah untuk mengukur konsistensi dari masingmasing indikator terhadap konstruknya. Suatu kelompok indikator dikatakan memiliki realibitas komposit yang baik jika nilai $\mathrm{CR} \geq 0.7$.

b) Inner model

Uji kelayakan model pada model struktural (inner model) diukur dengan menggunakan $R$ square variabel laten dependen seperti halnya dengan uji pada persamaan regresi. Namun selain $R$ Square kita juga harus memperhatikan nilai $Q$ Square Predictive Relevance yang bertujuan untuk mengukur seberapa baik nilai yang dihasilkan dari model dan estimasinya. Jika $Q$ Square $>0$ maka dapat dikatakan model memiliki predictive relevance yang baik, dan sebaliknya jika $Q$ Square $\leq 0$ maka model dianggap kurang memiliki predictive relevance.

7. Pengujian hipotesis dengan metode Bootstrap Metode Bootstrap memungkinkan penggunaan jumlah data yang sedikit pada regresi dengan Partial Least Square. Hal ini terjadi karena pada metode ini dilakukan resampling yang memungkinkan data dapat terdistribusi normal. Hipotesis diuji dengan menggunakan uji t di mana jika p-value $\leq 0.05$ maka disimpulkan terdapat hubungan signifikan antar variabel.

\section{HASIL PENELITIAN}

\subsection{Pengeluaran Pemerintah}

Pulau Kalimantan sebagai salah satu pulau besar yang berada di tengah kepulauan Indonesia saat ini memiliki 5 provinsi yang terdiri atas Kalimantan Barat, Kalimantan Tengah, Kalimantan Selatan, Kalimantan Timur, dan provinsi termuda pecahan dari Kalimantan Timur yaitu Kalimantan Utara. Total jumlah kabupaten dan kota dari kelima provinsi tersebut adalah 56 dengan 12 kabupaten dan 2 kota di Kalimantan Barat, 1 kota dan 13 kabupaten di Kalimantan Tengah, 2 kota dan 11 kabupaten di Kalimantan Selatan, 7 kabupaten dan 3 kota di Kalimantan Timur, dan 1 kota dan 4 kabupaten di Kalimantan Utara.

Literatur menyebutkan bahwa pengeluaran pemerintah secara umum berperan penting dalam mendorong pertumbuhan ekonomi dan meningkatkan kesejahteraan masyarakat. Peningkatan kesejahteraan masyarakat ini diharapkan terjadi terutama apabila pengeluaran pemerintah yang dimaksud difokuskan pada bidang yang yang berimbas langsung pada tujuan seperti pengeluaran bidang kesehatan, pendidikan, ekonomi, dan perlindungan sosial. Pada Anggaran Pendapatan dan Belanja Daerah (APBD) masingmasing wilayah dapat diketahui komitmen pemerintah dalam mengalokasikan anggaran untuk memperkecil ketimpangan distribusi pendapatan dan menurunkan angka kemiskinan. Di bidang kesehatan terlihat bahwa komitmen pemerintah provinsi di Kalimantan cenderung fluktuatif dalam kurun waktu tiga tahun terakhir dimana pertumbuhan alokasi pemerintah daerah di Kalimantan Barat di bidang tersebut mengalami kenaikan sebesar 63 dan 67\% di tahun 2016 dan 2017. Sedangkan di bidang pendidikan, ekonomi, dan sosial terjadi penurunan alokasi pengeluaran pemerintah dalam kurun waktu yang sama. Pertumbuhan terbesar terjadi pada pengeluaran pemerintah bidang pendidikan tahun 2016 yang mencapai $82 \%$ dibandingkan tahun sebelumnya, sedangkan pertumbuhan paling sedikit ada pada pengeluaran pemerintah bidang sosial di mana tahun 2016 dengan pertumbuhan $-6 \%$.

Serupa dengan progres pengeluaran pemerintah di Kalimantan Barat, pertumbuhan pengeluaran pemerintah terbesar di Kalimantan Tengah terjadi di bidang pendidikan pada tahun 2016 dan menurun tajam menjadi $26 \%$ di tahun 2017. Sementara alokasi di bidang kesehatan tidak mengalami penurunan anggaran dengan pertumbuhan sebesar 65\% sejak tahun 2015 2017. Di luar prioritas pendidikan dan kesehatan, tampaknya pemerintah di Kalimantan Tengah sedang mengurangi porsi pengeluaran bidang ekonomi di mana untuk pertumbuhan pengeluaran di bidang ekonomi tercatat $-7 \%$ dan $-1 \%$ di tahun 2016 dan 2017, dan di bidang sosial sedikit meningkat menjadi $16 \%$ setelah sebelumnya hanya tumbuh $2 \%$.

Data pada gambar 1 (lihat lampiran) menunjukkan bahwa senada dengan provinsi lainnya di Kalimantan, Kalimantan Selatan cenderung memprioritaskan bidang kesehatan dengan pertumbuhan pengeluaran pemerintah di bidang tersebut sebesar $76 \%$ dan $56 \%$ untuk tahun 2016 dan 2017. Sedangkan pada periode yang sama pertumbuhan bidang pendidikan menurun sebanyak $71 \%$ dan tumbuh kembali sebesar $46 \%$. Sebagai kompensasi dari tingginya pertumbuhan pengeluaran di bidang kesehatan dan pendidikan, pertumbuhan pengeluaran di bidang ekonomi dan sosial tergolong rendah karena hanya sebesar $-7 \%$ dan 2\% di tahun 2017.

Kalimantan Timur sebagai daerah dengan APBD terbesar di wilayah Kalimantan ternyata memiliki prioritas serupa dengan provinsi lainnya di bidang kesehatan dengan pertumbuhan alokasi pengeluaran pemerintah di bidang tersebut sebesar $73 \%$ pada tahun 2016, dan sedikit diturunkan 
menjadi 52\% tahun 2017. Ditengarai salah satu kompensasi dari tingginya pertumbuhan pengeluaran pemerintah ini adalah penurunan alokasi di bidang pendidikan di mana dibandingkan dengan data tahun 2015 prioritas anggaran untuk bidang tersebut turun sebesar $44 \%$ dan kembali diturunkan 3\% di tahun 2017. Di bidang ekonomi terjadi peningkatan pertumbuhan pengeluaran sebesar 21\% di tahun 2016, dan 14\% di tahun 2017. Sedangkan di bidang perlindungan sosial alokasi anggaran turun 13\% di tahun 2016 dan dinaikkan kembali sebesar 5\% di tahun 2017.

Hal menarik ditemukan dalam alokasi pengeluaran pemerintah di provinsi termuda Indonesia, Kalimantan Utara. Di tahun 2016 pertumbuhan anggaran pemerintah untuk kesehatan mengalami penurunan luar biasa hingga mencapai 133\% dibandingkan tahun 2015, demikian pula pertumbuhan alokasi anggaran ekonomi dan sosial yang turun sebesar $13 \%$ dan $34 \%$ di periode yang sama. Terlepas dari penyebab penurunan anggaran pendidikan ini tidak bisa dikatakan bahwa bidang kesehatan tidak menjadi prioritas pembangunan di Kalimantan Utara karena di tahun berikutnya progres anggaran untuk bidang ini naik sebesar 90\%. Masih di tahun 2016 penurunan alokasi anggaran rupanya tidak terjadi pada sektor pendidikan. Hal ini terlihat dari komitmen pemerintah yang mengalokasikan pengeluaran di bidang tersebut dengan progres sebesar 76\% di tahun 2016 dan 33\% di tahun 2017.

Fluktuasi pertumbuhan pengeluaran pemerintah tidak serta-merta menjadi indikator yang menentukan komitmen pemerintah daerah dalam bidang tertentu. Banyak faktor yang menjadi latar belakang situasi tersebut tidak hanya terbatas pada kemampuan anggaran dan prioritas kegiatan jangka pendek dan jangka panjang saja, tetapi perlu digarisbawahi bahwa kebijakan politik anggaran seharusnya disesuaikan dengan tujuan spesifik yang ingin dicapai seperti pemerataan distribusi pendapatan, pengentasan kemiskinan, pertumbuhan ekonomi, dan kesejahteraan penduduk secara keseluruhan.

\subsection{Distribusi Pendapatan}

Kesejahteraan suatu wilayah dapat diukur melalui banyak indikator antara lain ketimpangan distribusi pendapatan dan angka kemiskinan. Ketimpangan distribusi pendapatan adalah ukuran untuk melihat ketidakmerataan perekonomian sehingga pembangunan yang hanya berimbas pada sekelompok penduduk tertentu dapat dihindari. Ukuran yang dipakai umum untuk mengetahui ketimpangan distribusi pendapatan ini salah satunya adalah indeks Gini. Secara umum angka indeks Gini di Kabupaten/Kota di Pulau Kalimantan adalah 0,32 masih berada di bawah rata-rata nasional yaitu 0,39 dan jauh di bawah DI Yogyakarta yang memiliki indeks Gini 0,44. Indeks
Gini lima provinsi di Pulau Kalimantan dapat dilihat pada Gambar 2 di lampiran.

Indeks Gini tertinggi terjadi di Kalimantan Selatan dengan angka indeks mencapai 0,33 sedangkan provinsi lain seperti Kalimantan Barat, Kalimantan Tengah dan Kalimantan Utara memilki indeks Gini sebesar 0.31. Angka indeks Gini bergerak dari 0 sampai dengan 1 dimana angka 0 merupakan representasi dari distribusi pendapatan penduduk yang sangat merata dan angka 1 diterjemahkan sebagai distribusi pendapatan yang sangat tidak merata. Literatur menyebutkan bahwa angka indeks Gini berhubungan erat angka kemiskinan yaitu semakin tinggi indeks Gini biasanya diikuti dengan tingginya tingkat kemiskinan.

Kemiskinan penduduk di 5 provinsi di Kalimantan dapat ditelaah dari kondisi kemiskinan berdasarkan persentase penduduk miskin (P0), kedalaman kemiskinan (P1), dan keparahan kemiskinan (P2). Di antara kelima provinsi di persentase penduduk miskin tertinggi ada di wilayah Kalimantan Barat dengan angka rata-rata sebesar 8,18\% selama kurun waktu 3 tahun, disusul oleh Kalimantan Timur sebesar 6,7\%, Kalimantan Utara 6,32\%, Kalimantan Tengah 5,57\%, dan Kalimantan Selatan persentase penduduk miskin terkecil yaitu 5,09\%. Dilhat dari angka sebenarnya persentase penduduk miskin ini sepanjang tahun semakin menunjukkan penurunan terutama di wilayah Kalimantan Tengah dan Selatan, sedangkan di 3 provinsi yang lain persentase penduduk miskin terus mengalami peningkatan. Selain persentase penduduk miskin, ukuran lain yang digunakan untuk mengukur kemiskinan adalah indeks kedalaman dan indeks keparahan kemiskinan. Indeks kedalaman kemiskinan adalah representasi dari kesenjangan antara pengeluaran penduduk miskin dengan garis kemiskinan, di mana semakin tinggi nilai indeks semakin jauh jarak pengeluaran dari garis kemiskinan yang sudah ditetapkan. Garis kemiskinan itu sendiri merupakan jumlah pengeluaran rumah tangga yang terdiri atas pengeluaran untuk makanan dan non makanan. Indeks keparahan kemiskinan merupakan gambaran ketimpangan pengeluaran antar penduduk yang berada di bawah garis kemiskinan. Indeks ini diinterpretasikan sebagai semakin tinggi angka indeks keparahan kemiskinan, semakin timpang/besar perbedaan pengeluaran antar penduduk miskin. Indeks kedalaman kemiskinan (P1) di seluruh wilayah Kalimantan masih berada di bawah 3\% dengan rata-rata angka indeks sebesar 0,29 untuk Kalimantan Barat, 0,17 di Kalimantan Tengah, 0,16 angka indeks Kalimantan Selatan, serta 0,24 dan 0,22 masing-masing untuk Kalimantan Timur dan Utara. Dengan demikian angka indeks keparahan kemiskinan untuk wilayah Kalimantan masih jauh lebih baik dari tiga provinsi dengan indeks kedalaman tertinggi di Indonesia 
yaitu Papua Barat, Papua, dan Nusa Tenggara Timur yang masing-masing mencapai angka 6,5, 5,9, dan $4,5^{2}$.

\subsection{Analisis Outer Model}

Langkah pertama dalam menjawab pertanyaan penelitian ini adalah menentukan dan membentuk model struktural berdasarkan konsep dan teori yang menghasilkan diagram ... Berdasarkan telaah teoritis dan konseptual terdapat hubungan antara variabel endogen dan eksogen yaitu variabel kemiskinan, distribusi pendapatan dan pengeluaran pemerintah. Ketiga variabel ini adalah variabel laten yang memiliki variabel manifest/indikator bersifat reflektif. Variabel laten kemiskinan direfleksikan oleh tiga variabel manifest yaitu persentase kemiskinan, keparahan kemiskinan, dan kedalaman kemiskinan. Variabel laten ketimpangan pendapatan adalah refleksi dari angka koefisien Gini, sedangkan variabel laten pengeluaran pemerintah direfleksikan dari pengeluaran pemerintah bidang pendidikan, kesehatan, ekonomi, dan perlindungan sosial. Berikut adalah diagram jalur dan nilai loading factor untuk masing-masing variabel laten dan manifest dalam penelitian. Nilai loading factor pada diagram 1 menunjukkan koefisien untuk masing-masing variabel manifest terhadap variabel laten, di mana koefisien tersebut menunjukkan reliabilitas indikator yang dapat dijelaskan oleh variabel laten. Pada posisi ini literatur menyebutkan bahwa suatu indikator/variabel manifes reflektif yang memiliki nilai loading $(\lambda)$ lebih kecil dari 0.4 sebaiknya dikeluarkan dari model karena kurang mencerminkan variabel laten. Dengan demikian pada penelitian ini variabel manifest untuk PEND2 dan GR3 dikeluarkan dari model karena nilai loading masing-masing adalah 0.477 dan 0.416 dan menghasilkan diagram konstruk pada gambar 2 dimana ketahui bahwa loading faktor dari setiap variabel laten sudah lebih besar dari 0.5 (gambar 3 dan 4 di lampiran). Seperti yang sudah disampaikan pada bagian tulisan sebelumnya uji outer model meliputi convergent validity, discriminant validity, dan composite reliability. Output dari model yang diolah dengan menggunakan software smartPLS dapat dilihat pada tabel 2 (lampiran).

a) Convergent validity

Luaran perhitungan koefisien dengan mengunakan smartPLS2 mendapatkan nilai loading factor untuk masing-masing indikator/variabel manifest dengan nilai Average Variance Extracted (AVE) yang diharapkan adalah $>0.5$. Setelah mengeleminasi dua indikator yang dengan loading factor yang memiliki skor di bawah 0.5 maka seluruh nilai AVE untuk ketiga variabel laten telah memiliki nilai AVE > 0.5. dengan demikian secara keseluruhan indikator dalam penelitian ini mampu menjelaskan konstruknya dengan baik.

\section{b) Discriminant validity}

Pengukuran validitas selanjutnya dilakukan dengan melihat nilai cross loading. Suatu indikator dinyatakan valid jika pada konstruk tertentu memiliki nilai loading factor tertinggi dibandingkan dengan nilai loading factor pada konstruk yang lain. dan membandingkan nilai loading factor masingmasing indikator pada konstruk tertentu dengan loading factor pada konstruk yang lain. Luaran cross loading dalam penelitian ini dapat dilihat pada bagian lampiran, dan hasil output menunjukkan bahwa outer model penelitian ini valid.

c) Composite reliability

Pengukuran reliabilitas untuk masing-masing variabel laten dapat dilihat dari nilai Cronbach's alpha dan composite reliability. Berdasarkan tabel 1 diketahui semua variabel laten memiliki nilai composite reliability $>0.7$ sehingga dapat dikatakan indikator yang digunakan dalam model penelitian ini dapat diandalkan meskipun pada variabel laten INC_DIST nilai Cronbachs' alpha hanya sebesar 0.39.

\subsection{Analisis Inner Model}

Analisis model struktural dilakukan untuk melihat hubungan kausal antara variabel laten eksogen dan endogen. Analisis yang digunakan adalah Goodness of Fit model yang diukur melalui $R$ Square variabel laten dependen dan pemaknaan yang sama dengan model regresi. Penelitian ini menghasilkan $R$ Square yang kecil dengan nilai hanya sebesar 0.04 , artinya variabel pengeluaran pemerintah yang diakomodir dalam penelitian ini secara parsial tidak mampu menjelaskan variabel laten ketimpangan pendapatan dan kemiskinan. Selain $R$ Square analisis inner model juga dapat juga menggunakan nilai $Q$ Square, di mana uji ini dimaksudkan untuk melihat apakah model mempunyai relevansi prediktif. Saat ini software smartPLS v2.0 belum menyediakan perhitungan untuk $Q$ Square sehingga penelitian ini hanya menggunakan angka $R$ Square seperti yang sudah disebutkan sebelumnya.

Evaluasi inner model juga dilakukan pada koefisien parameter jalur melalui nilai $\mathrm{t}$ statistik dengan metode Bootstrapping. Proses Bootstrapping dengan jumlah sampel sebanyak 61 dan pengulangan sebanyak 200 kali menghasilkan signifikansi hubungan antar variabel eksogen dan endogen penelitian sebagaimana dapat dilihat pada tabel 3 yang terdapat di lampiran. Uji signifikansi dengan taraf 5\% diketahui bahwa variabel eksogen pengeluaran pemerintah (GOV_SPENDING) berpengaruh signifikan terhadap variabel endogen ketimpangan pendapatan (INC_DIST) dengan $t$ statistik sebesar 2,49 lebih besar dari t kritis 1,96. Variabel eksogen ketimpangan pendapatan 
(INC_DIST) berpengaruh signifikan terhadap variabel endogen kemiskinan (POV) dengan nilai $t$ statistik sebesar 2,86 > 1,96. Berdasarkan uji signifikansi ini artinya variabel pengeluaran pemerintah memiliki positif dan signifikan terhadap variabel ketimpangan pendapatan, sebagaimana halnya pengaruh negatif signifikan variabel ketimpangan pendapatan terhadap kemiskinan. Berbeda dengan uji signifikansi variabel pengeluaran pemerintah (GOV_SPENDING) terhadap variabel kemiskinan (POV) luaran yang dihasilkan oleh perhitungan metode Partial Least Square tidak menunjukkan signikansi antar kedua variabel di mana t statistik variabel eksogen adalah $0,45<1,96$. Artinya hubungan positif antara kedua variabel tersebut secara nyata tidak dapat dibuktikan.

Berdasarkan luaran perhitungan smartPLS didapatkan 2 (dua) persamaan untuk model struktural kemiskinan di Pulau Kalimantan yaitu:

$$
\text { Ketimpangan Pendapatan=0,225259 }
$$

Pengeluaran Pemerintah $+\zeta$

Kemiskinan $=-0,213112$

Ketimpangan Pendapatan $+0,050223$ Pengeluaran Pemerintah $+\zeta$

\subsection{Pembahasan}

Variabel pengeluaran pemerintah (GOV_SPEND) memiliki koefisien positif dan secara signifikan berpengaruh terhadap variabel ketimpangan pendapatan (INC_DIST). Hal ini berarti peningkatan pengeluaran pemerintah akan meningkatkan pemerataan distribusi pendapatan penduduk Pulau Kalimantan. Di dalam postur APBD pengeluaran pemerintah berdasarkan fungsinya terbagi menjadi 11 (sebelas) item antara lain fungsi pendidikan, kesehatan, ekonomi, ketertiban dan ketenteraman, lingkungan hidup, pariwisata dan budaya, pelayanan umum, perlindungan sosial, perumahan dan fasilitas umum, dan fungsi lainnya. Dari ke sebelas fungsi pada pengeluaran pemerintah tersebut terdapat 4 (empat) fungsi yang terkait langsung dengan penanggulangan kemiskinan yaitu fungsi ekonomi, pendidikan, kesehatan, dan perlindungan sosial. Distribusi pendapatan sebagai variabel endogen adalah pernyataan negatif dari rasio Gini yang merupakan ukuran ketimpangan pendapatan penduduk dengan kisaran nilai $0<x<1$. Nilai 0 adalah pemerataan sempurna (distribusi pendapatan penduduk merata) dan 1 adalah ketidakmerataan sempurna (distribusi pendapatan penduduk sangat tidak merata). Artinya semakin rasio Gini mendekati nilai 0 , semakin baik pemerataan pendapatan penduduk di suatu wilayah. Menariknya saat variabel pengeluaran pemerintah ini didekompisisi secara parsial dan diolah data berdasarkan fungsi masingmasing tidak ada satu pun variabel yang secara signifikan menjelaskan perubahan pada distribusi pendapatan. Hal ini merupakan indikasi bahwa alokasi pengeluaran pemerintah seharusnya didorong secara simultan sehingga tujuan pemerataan distribusi pendapatan dengan cara memperkecil ketimpangan dapat tercapai.

Berdasarkan data Pulau Kalimantan diketahui variabel kemiskinan secara negatif signifikan dipengaruhi oleh ketimpangan pendapatan dan secara positif dipengaruhi oleh pengeluaran pemerintah meskipun tidak signifikan. Sama halnya dengan rasio Gini variabel kemiskinan yang merupakan refleksi dari persentase jumlah penduduk miskin dan indeks kedalaman kemiskinan, adalah sebuah pernyataan negatif di mana semakin besar angka kemiskinan berarti semakin buruk situasi kemiskinan di wilayah tersebut. Hasil penelitian menyebutkan bahwa ketimpangan pendapatan berpengaruh negatif terhadap kemiskinan. Artinya semakin besar ketimpangan distribusi pendapatan berimplikasi pada semakin tingginya tingkat kemiskinan di wilayah tersebut. Di sisi yang lain temuan penelitian menyebutkan bahwa pengeluaran pemerintah berpengaruh positif tetapi tidak signifikan terhadap kemiskinan. Koefisien positif menunjukkan bahwa besarnya pengeluaran pemerintah tidak berimplikasi pada semakin membaiknya situasi kemiskinan di Kalimantan. Temuan ini, meskipun tidak dapat dibuktikan secara nyata melalui data penelitian, kontradiktif dengan beragam teori dan literatur yang menyatakan bahwa alokasi pengeluaran pemerintah memiliki andil besar dalam menurunkan angka kemiskinan. Namun demikian situasi tersebut bisa saja terjadi saat pengeluaran pemerintah tidak secara spesifik dimaksudkan hanya untuk mengentaskan kemiskinan atau program-program yang dilaksanakan melalui alokasi anggaran tersebut tidak tepat sasaran. Kemungkinan lainnya dari situasi ini adalah peran distributif pemerintah belum dapat dilihat dalam kurun waktu yang relatif sebentar sehingga alokasi anggaran tersebut belum dirasakan manfaatnya untuk meningkatkan kesejahteraan melalui menurunnya angka kemiskinan.

\section{KESIMPULAN DAN SARAN}

Sesuai dengan hasil analisis data penelitian ini menghasilkan kesimpulan antara lain

1) Variabel laten ketimpangan pendapatan pada awalnya terdiri atas 3 (tiga) variabel manifest/indikator, tetapi setelah dievaluasi salah satu dari ketiga indikator tersebut harus dikeluarkan dari model karena memiliki nilai loading factor lebih rendah dari yang disyaratkan. Demikian pula halnya dengan 1 dari 9 (sembilan) variabel manifest reflektif variabel laten pengeluaran pemerintah. Penulis mengeluarkan satu indikator yang merefleksikan pengeluaran pemerintah bidang pendidikan karena memiliki loading 
factor variabel tersebut lebih kecil dari syarat yang ditentukan.

2) Pengeluaran pemerintah memiliki koefisien positif dan secara signifikan berpengaruh terhadap variabel ketimpangan distribusi pendapatan. Artinya peningkatan pengeluaran pemerintah di bidang ekonomi, pendidikan, kesehatan, dan bantuan sosial akan meningkatkan pemerataan distribusi pendapatan penduduk Pulau Kalimantan.

3) Ketimpangan distribusi pendapatan berpengaruh positif dan signifikan terhadap kemiskinan, sebaliknya pengeluaran pemerintah berpengaruh negatif terhadap angka kemiskinan meskipun tidak bisa dibuktikan secara statistik untuk kasus Kalimantan. Hubungan positif menunjukkan bahwa semakin tinggi angka ketimpangan distribusi pendapatan bermakna pada semakin meningkatnya angka kemiskinan di wilayah tersebut. Sementara hubungan negatif pada pengeluaran pemerintah berimplikasi pada beragam kemungkinan seperti ketidaktepatan dalam menentukan program dan sasaran pengentasan kemiskinan atau pengeluaran pemerintah belum atau tidak memberikan dampak terhadap kemiskinan. Secara teknis hal tersebut dimungkinkan mengingat jumlah time series data yang digunakan relatif sedikit.

\section{IMPLIKASI DAN KETERBATASAN}

Hasil penelitian menunjukkan bahwa variabel pengeluaran pemerintah berpengaruh positif dan signifikan terhadap variabel ketimpangan distribusi pendapatan di wilayah Kalimantan. Hal ini berimplikasi pada pentingnya peran pemerintah dalam memperkecil ketimpangan distribusi pendapatan melalui alokasi pengeluaran pemerintah di bidang pendidikan, kesehatan, ekonomi, dan perlindungan sosial. Seperti disebutkan sebelumnya penelitian ini membuktikan bahwa semakin besar pengeluaran pemerintah maka akan semakin meningkatkan pemerataan distribusi pendapatan penduduk. Namun demikian tetap perlu dipikirkan seberapa jauh peran pemerintah ini mampu mendorong pemerataan distribusi pendapatan terutama di wilayah penelitian sehingga bisa diketahui titik optimalnya. Lebih lanjut, dari hasil penelitian diketahui bahwa pengeluaran pemerintah tidak berpengaruh secara signifikan terhadap menurunkan kemiskinan di wilayah penelitian, sedangkan ketimpangan distribusi berpengaruh negatif signifikan terhadap kemiskinan. Implikasi dari temuan ini adalah ternyata pengeluaran pemerintah untuk bidangbidang yang disebutkan sebelumnya tidak dapat secara langsung mempengaruhi kemiskinan baik dalam hal menurunkan persentase penduduk miskin maupun angka kedalaman dan keparahan kemiskinan. Pengeluaran pemerintah dapat menurunkan angka kemiskinan melalui mekanisme pemerataan distribusi pendapatan, sehingga sebaiknya pengeluaran pemerintah lebih diprioritaskan untuk program-program yang mendorong aktivitas ekonomi menjadi lebih merata dan pada gilirannya akan menurunkan kemiskinan. Selain implikasi kebijakan di atas terdapat paling sedikit dua batasan dalam penelitian ini, yaitu:

1) Data pengeluaran pemerintah yang digunakan dalam penelitian tidak dapat di-dekomposisi berdasarkan kategori jenis belanja langsung dan tidak langsung sehingga tidak diketahui proporsi anggaran yang spesifik dipergunakan untuk kebutuhan pembangunan. Artinya meskipun secara keseluruhan pengeluaran pemerintah untuk bidang-bidang yang disebutkan sebelumnya berpengaruh signifikan, sulit untuk menentukan apakah hal tersebut disebabkan oleh pengeluaran untuk belanja langsung atau tidak, dan

2) Penggunaan data panel memungkinkan tersedianya klasifikasi data yang lebih variatif mengenai wilayah penelitian namun ketersediaan data yang seragam untuk setiap daerah sering kali tidak tersedia dalam jangka waktu yang lebih panjang. Konsekuensinya kekosongan data diestimasi dengan menggunakan metode matematis sehingga data yang ada bukan merupakan kondisi faktual lapangan.

\section{REFERENSI}

Artige, L., \& Cavenaile, L. (2004). Public education expenditures and growth. Journal of Development Economics, 73(2), 583-605. https://doi.org/10.1016/j.jdeveco.2003.05.004

Barro, R. J. (2000). Inequality and growth in a panel of countries. Journal of Economic Growth, 5, 2-48.

Bénabou, R. (2000). Unequal societies: income distribution and the social contract. American Economic Review, 90(1), 96-129. https://doi.org/10.1257/aer.90.1.96

Bleaney, M., Gemmell, N., \& Kneller, R. (2001). Testing the endogenous growth model: public expenditure, taxation, and growth over the long run. Canadian Journal of Economics, 34(1), 3657. https://doi.org/10.1111/0008-4085.00061

Checchi, D. (2000). Does Educational Achievement Help to Explain Income Inequality? http://wp.demm.unimi.it/files/wp/2000/DEM M-2000_011wp.pdf

Coady, D., \& Dizioli, A. (2017). Income inequality and education revisited: persistence, endogeneity, and heterogeneity. IMF Working Paper, WP/17/126.

https://www.imf.org/en/Publications/WP/Iss ues/2017/05/26/Income-Inequality-andEducation-Revisited-Persistence-Endogeneityand-Heterogeneity-44854 
Glomm, G., \& Ravikumar, B. (1992). Public versus private investment in human capital: endogenous growth and income inequality. Journal of Political Economy, 100(4), 818-834. https://doi.org/10.1086/261841

Hoechle, D. (2007). Robust standard errors for panel regressions with cross-sectional dependence. Stata Journal, 7(3), 281-312. https://doi.org/10.1177/1536867x070070030 1

Jianu, I. (2018). The impact of government health and education expenditure on income inequality in European Union. Theoretical and Applied Economics. Special Issue, 121-134. Retrieved from http://www.ectap.ro/supliment/internationalfinance-and-banking-conference-fi-ba-2018xvith- edition/28

Keller, R. K. (2010). How Can education policy improve income distribution?: an empirical analysis of education stages and measures on income inequality. The Journal of Developing Areas, 43(2), 51-77. https://doi.org/10.1353/jda.0.0052

Moene, K. ., \& Wallerstein, M. (2001). Inequality, social insurance, and redistribution. American Political Science Review, 95(4), 859-874. http://www.people.fas.harvard.edu/ iversen/ PDFfiles/Moene\&Wallerstein2001.pdf

Ospina, M. (2014). The effect of social spending on income inequality: an analysis for Latin American countries. SSRN Electronic Journal, (10). https://doi.org/10.2139/ssrn.2427510

Romer, P. M., Becker, G., Shell, K., Lucas, R., Grossman, G., \& Helpinan, E. (1989). Romer 1989 (1991) Endogenous technological growth, (3210). http://pages.stern.nyu.edu/ promer/Endogen ous.pdf

Sylwester, K. (2002). Can education expenditures reduce income inequality? Economics of Education Review, 21(1), 43-52. https://doi.org/10.1016/S02727757(00)00038-8

Ulu, M. I. (2018). The effect of government social spending on income inequality in oecd: A panel data analysis, (91104). https://mpra.ub.unimuenchen.de/id/eprint/91104

\section{LAIN-LAIN}

Direktur Jenderal Perimbangan Keuangan Kementerian Keuangan Republik Indonesia http://www.djpk.kemenkeu.go.id/?p=5412 diakses tanggal 6 November 2019

Badan Pusat Statistik https://www.bps.go.id/linkTableDinamis/view /id/1121 diakses tanggal 11 Nopember 2019 


\section{ILUSTRASI TABEL}

Tabel 1. Variabel Penelitian

\begin{tabular}{|c|c|c|c|}
\hline Variabel Laten & Kode & $\begin{array}{c}\text { Indikator } \\
\text { (Variabel Manifest) }\end{array}$ & Kode \\
\hline $\begin{array}{c}\text { Pengeluaran } \\
\text { Pemerintah } \\
\text { (Laten Eksogen) }\end{array}$ & GOV_SPEND & $\begin{array}{l}\begin{array}{l}\text { 1. Pengeluaran } \\
\text { pemerintah bidang } \\
\text { kesehatan }\end{array} \\
\text { 2. Pengeluaran } \\
\text { pemerintah bidang } \\
\text { pendidikan } \\
\text { 3. Pengeluaran } \\
\text { pemerintah bidang } \\
\quad \text { ekonomi } \\
\text { 4. Pengeluaran } \\
\text { pemerintah untuk } \\
\text { bantuan sosial }\end{array}$ & $\begin{array}{l}\text { 1. KES1 } \\
\text { 2. KES2 } \\
\text { 3. KES3 } \\
\text { 4. PEND1 } \\
\text { 5. PEND2 } \\
\text { 6. PEND3 } \\
\text { 7. EKO1 } \\
\text { 8. EKO2 } \\
\text { 9. EKO3 } \\
\text { 10. SOS2 } \\
\text { 11. SOS2 } \\
\text { 12. SOS3 }\end{array}$ \\
\hline $\begin{array}{c}\text { Ketimpangan } \\
\text { Pendapatan } \\
\text { (Laten Eksogen) }\end{array}$ & INC_DIST & Rasio Gini & $\begin{array}{l}\text { 1. GR1 } \\
\text { 2. GR2 } \\
\text { 3. GR3 }\end{array}$ \\
\hline $\begin{array}{c}\text { Kemiskinan } \\
\text { (Laten Endogen) }\end{array}$ & POV & $\begin{array}{c}\text { 1. Persentase } \\
\text { penduduk miskin } \\
\text { 2. Indeks kedalaman } \\
\text { kemiskinan } \\
\text { 3. Indeks keparahan } \\
\text { kemiskinan }\end{array}$ & $\begin{array}{l}\text { 1.P01 } \\
\text { 2.P02 } \\
\text { 3.P03 } \\
\text { 4.P11 } \\
\text { 5.P12 } \\
\text { 6.P13 } \\
\text { 7.P21 } \\
\text { 8.P22 } \\
\text { 9.P23 }\end{array}$ \\
\hline
\end{tabular}

Sumber: hasil olah data, 2019

Tabel 2. Evaluasi outer model

\begin{tabular}{cccc}
\hline & AVE & $\begin{array}{c}\text { Composite } \\
\text { Reliability }\end{array}$ & $\begin{array}{c}\text { Cronbachs } \\
\text { Alpha }\end{array}$ \\
\hline GOV_SPENDING & 0.693368 & 0.960769 & 0.955197 \\
INC_DIST & 0.624220 & 0.768609 & 0.398182 \\
POV & 0.763775 & 0.966468 & 0.961890 \\
\hline \multicolumn{2}{r}{ Sumber: olah data, 2019} \\
\end{tabular}

Tabel 3. Uji signifikansi antar variabel dengan metode Bootstrapping

\begin{tabular}{|c|c|c|c|c|c|}
\hline & $\begin{array}{c}\text { Original } \\
\text { Sample (0) }\end{array}$ & $\begin{array}{c}\text { Sample } \\
\text { Mean (M) }\end{array}$ & $\begin{array}{c}\text { Standard } \\
\text { Deviation } \\
\text { (STDEV) }\end{array}$ & $\begin{array}{c}\text { Standard } \\
\text { Error (STERR) }\end{array}$ & $\begin{array}{c}\text { T Statistik } \\
(|\mathrm{O} / \mathrm{STERR}| \text { ) }\end{array}$ \\
\hline $\begin{array}{r}\text { GOV_SPENDING- } \\
\text { >INC_DIST }\end{array}$ & $\mathbf{0 . 2 2 5 1 5 9}$ & $\mathbf{0 . 2 4 1 5 3 1}$ & $\mathbf{0 . 0 9 0 4 1 4}$ & $\mathbf{0 . 0 9 0 4 1 4}$ & 2.490322 \\
\hline $\begin{array}{c}\text { GOV_SPENDING- } \\
\text { >POV }\end{array}$ & $\mathbf{0 . 0 5 0 2 2 3}$ & $\mathbf{0 . 0 5 5 3 7 3}$ & $\mathbf{0 . 1 1 2 2 6 0}$ & $\mathbf{0 . 1 1 2 2 6 0}$ & $\mathbf{0 . 4 4 7 3 8 1}$ \\
\hline INC_DIST->POV & $\mathbf{- 0 . 2 1 3 1 1 2}$ & -0.235882 & 0.074564 & 0.074564 & 2.858090 \\
\hline
\end{tabular}

Sumber: olah data, 2019 


\section{ILUSTRASI GRAFIK}

Gambar 1. Pertumbuhan pengeluaran pemerintah se-Kalimantan 2015-2017

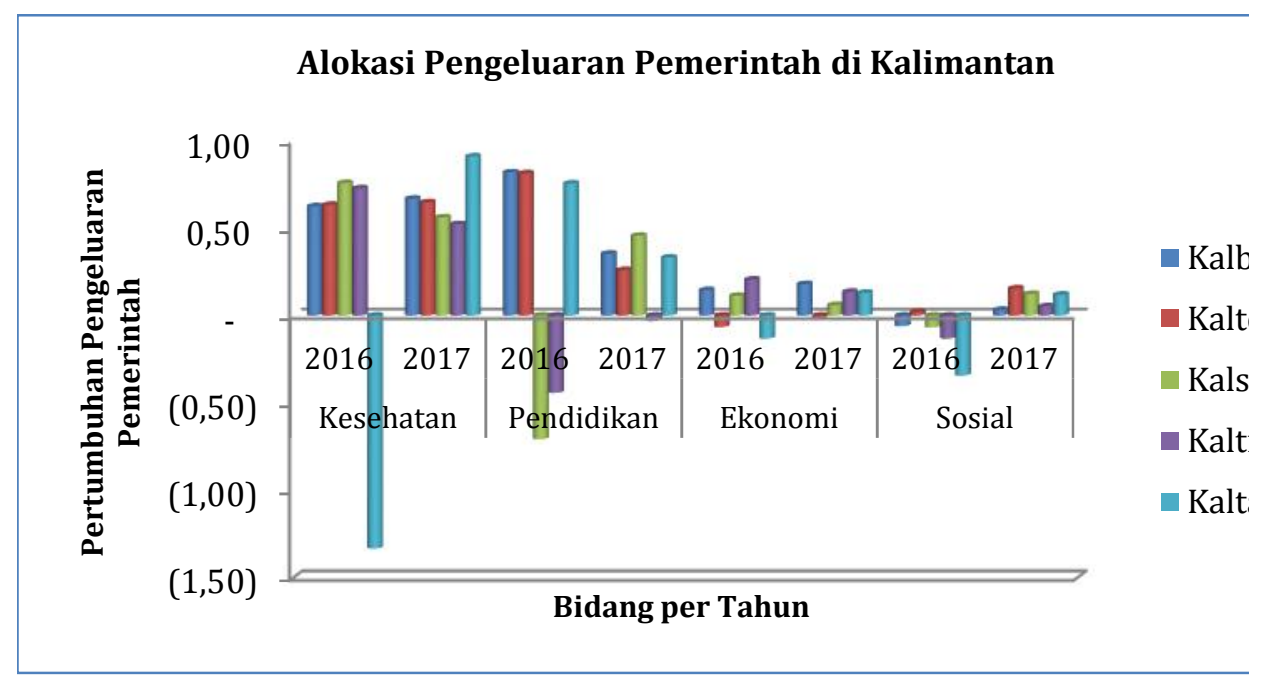

Sumber: Dirjen Perimbangan Keuangan, 2019

Gambar 2. Indeks Gini 5 Provinsi di Pulau Kalimantan 2015-2017

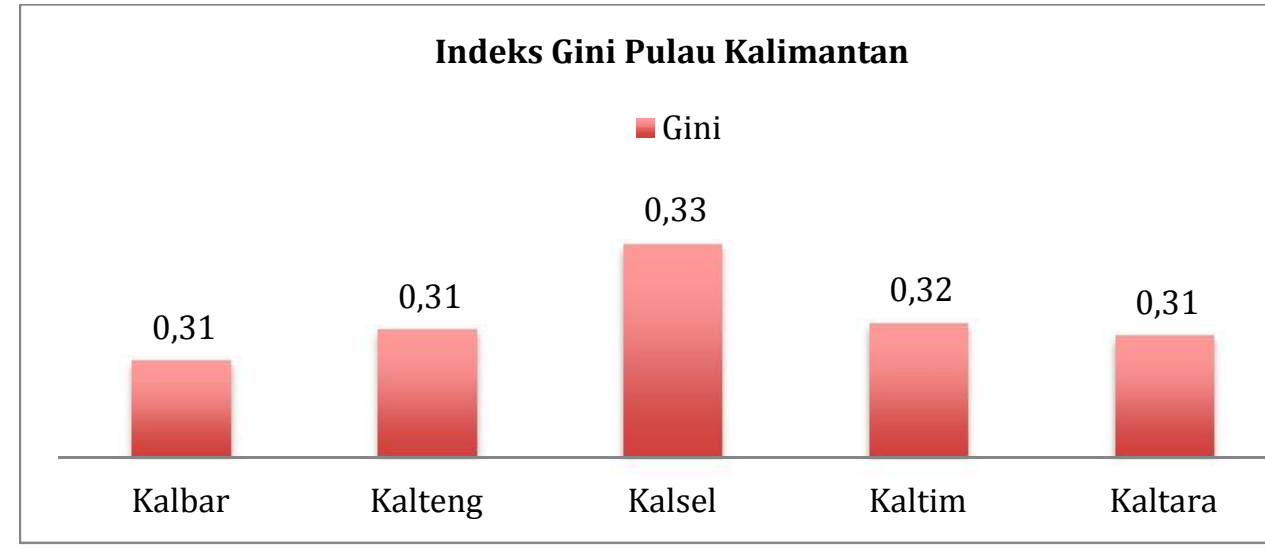

Sumber: Badan Pusat Statistik, 2019 
Gambar 3. Tingkat Kemiskinan di Pulau Kalimantan 2015-2017

Tingkat Kemiskinan Provinsi di Kalimantan

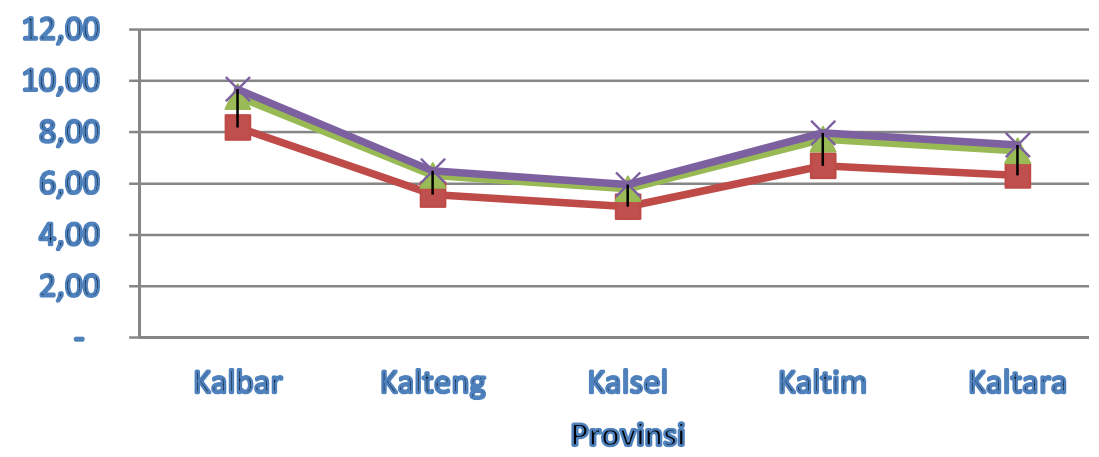

Sumber: Badan Pusat Statistik, 2019

Gambar 4. Diagram Jalur dan Nilai Loading Factor

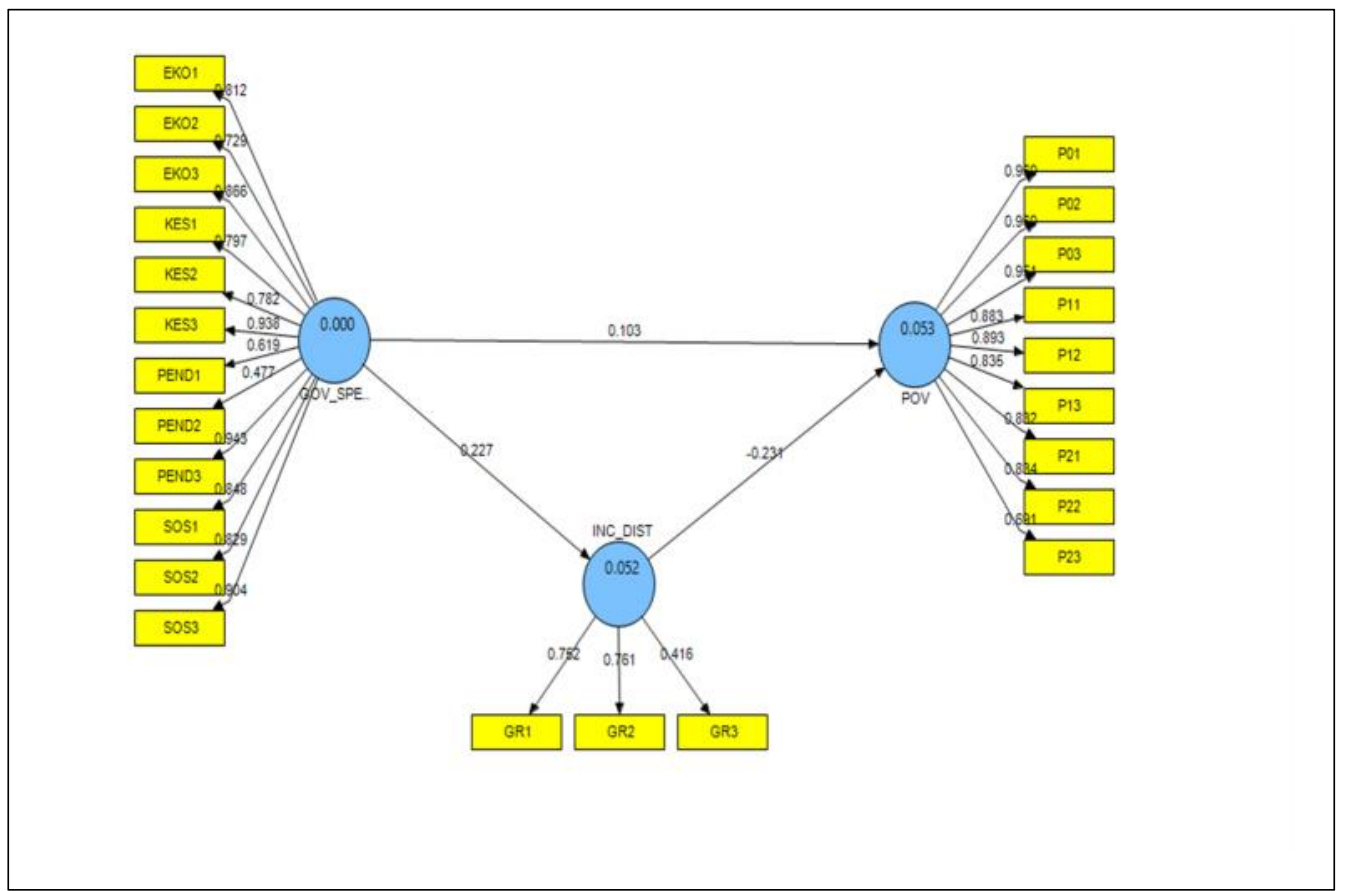

Sumber: olah data, 2019 
Gambar 5. Diagram Jalur dan Nilai Loading Factor setelah variabel manifest dikeluarkan

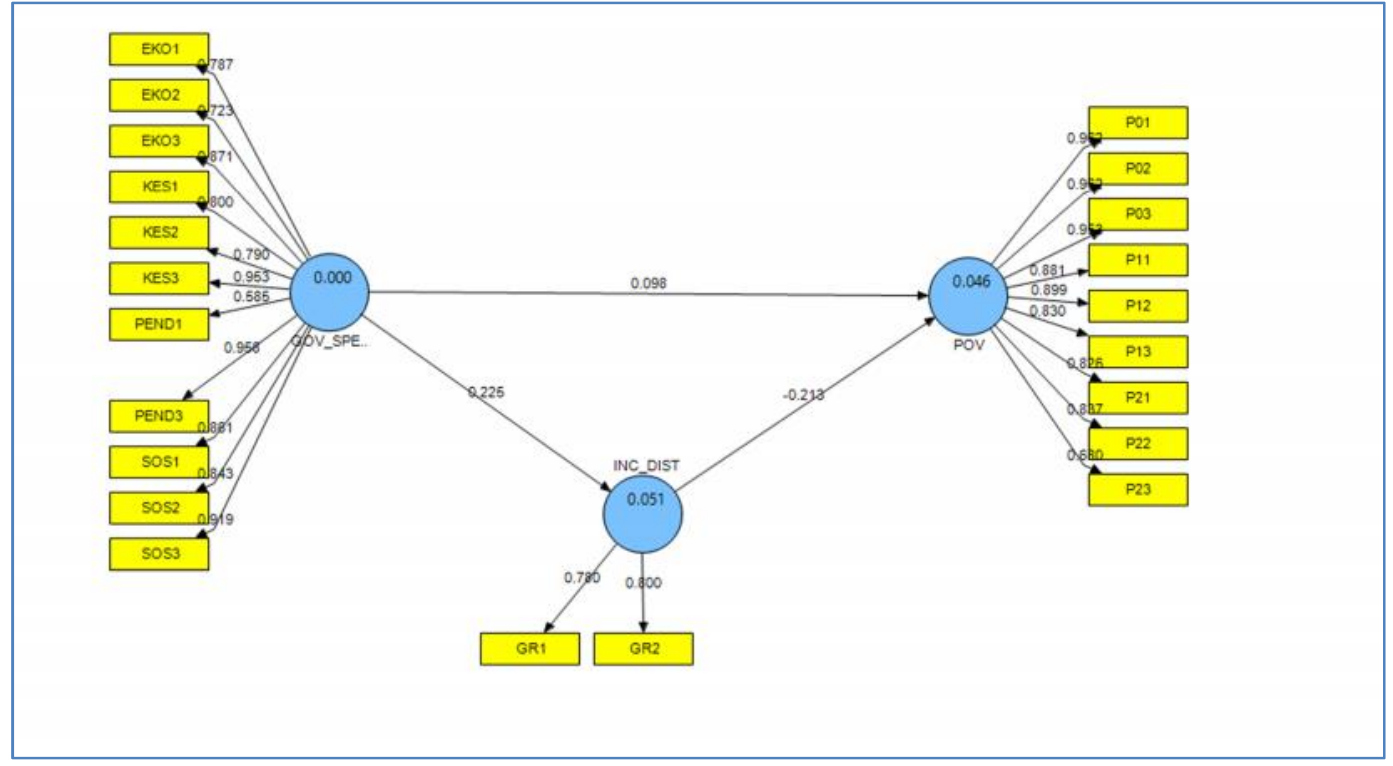

Sumber: olah data, 2019 